\title{
SISTEM INFORMASI PENGOLAHAN IKAN TUNA UNTUK KETERTELUSURAN PERIKANAN SKALA KECIL
}

\section{INFORMATION SYSTEM TUNA PROCESSING FOR TRACEABILITY IN SMALL SCALE FISHERY}

\author{
I Gede Sujana Eka Putra ${ }^{1 *}$, Stephani Mangunsong ${ }^{2)}$ \\ ${ }^{1)}$ STMIK STIKOM Indonesia \\ ${ }^{2)}$ Yayasan Masyarakat Dan Perikanan Indonesia, Istana Regency Blok S No7 Pesanggaran, Denpasar Bali
}

Diterima: 27 Januari 2019; Disetujui: 25 April 2019

\begin{abstract}
ABSTRAK
Pencatatan data pengolahan tuna secara manual kadangkala terjadi kesalahan pencatatan, kehilangan dan kerusakan dokumen data dan proses pencarian data manual yang memerlukan waktu yang lama. Tujuan penelitian ini adalah untuk mendigitalisasi pencatatan data pengolahan tuna melalui penggunaan kode internal lot pada setiap tahapan proses pengolahan tuna . Data sampel yaitu berat tuna sejumlah 32,6 ton dari 16 supplier, dan loin yang diproduksi sejumlah 24,5 ton. Metode yang digunakan pada penelitian ini adalah studi kasus dengan mengamati dan mendeskripkan sistem informasi pada perusahaan pengolahan tuna. Kajian sistem pengolahan tuna dilakukan pada periode 26 Januari-15 Februari 2018 melalui implementasi sistem pada jaringan komputer lokal dengan perangkat komputer, timbangan digital, printer label, dan scanner QR Code dengan penempatan komputer pada tiap tahapan proses yang terdiri dari receiving, cutting, retouching, packing dan stuffing. Hasil penelitian menunjukkan bahwa Informasi labe/ berupa kode quick response code (QR Code) yang berisi kode loin, jenis species, grade, berat loin, kode lot internal, kode supplier, jenis ikan, tanggal pengolahan, dan lokasi penangkapan. Melalui penerapan sistem informasi pengolahan tuna, membantu pengelolaan informasi yang baik untuk memudahkan penelusuran produk tuna.
\end{abstract}

Kata Kunci: Pencatatan, Pengolahan Data Tuna, Ketertelusuran, Digital, Sistem Informasi

\begin{abstract}
Tuna data recording and processing manually are often found a number of errors, loss, and harm to the data documents and data searching processes are also required a long time. The purpose of this study was to digitize tuna data processing and recording through the use of internal lot codes at each stage of the tuna processing process. Sample data were tuna weight of 32.6 tons from 16 suppliers and produced loin of 24.5 tons. The method used in this study was a case study by observing and describing information systems in tuna processing company. The tuna processing system study was carried out in the period of 26 January- 15 February 2018 through the implementation of a system on local computer networks with computer devices, digital scales, label printers, and QR Code scanners with computer placement at each process stage consisting of receiving, cutting, retouching, packing and stuffing. The results showed that label information was in the form of a Quick Response Code (QR Code) containing loin code, species type, grade, loin weight, internal lot code, supplier code, fish type, processing date, and fishing location. Through the application of a tuna processing information system, it helps manage good information to facilitate tracking of tuna products.
\end{abstract}

Keywords: Recording, Tuna data processing, Traceability, Digital, Information system 
Contact person : : I Gede Sujana Eka Putra

E-Mail : sujanaekaputra@stiki-indonesia.ac.id, sujana@mdpi.or.id

\section{PENDAHULUAN}

Pada perusahaan pengolahan perikanan, diperlukan pemanfaatan sistem informasi yang dapat mengelola data transaksi harian yang jumlahnya cukup besar. Berdasarkan pengertiannya, sistem sebagai aktivitas dengan aturan yang sistematis dan terstruktur untuk mencapai tujuan tertentu. Sementara informasi merupakan sejumlah data yang telah diolah untuk tujuan tertentu (Prasetyo, 2010; Rahajeng, 2012).

Sistem informasi mengelola data mentah untuk menjadi informasi yang membantu mengambil keputusan dengan tepat dan cepat, menghasilkan strategi baru bagi perusahaan, untuk perencanaan, pengendalian, dan perbaikan berkelanjutan. Kondisi saat ini beberapa perusahaan pengolahan ikan menggunakan formulir manual untuk mencatat transaksi pengolahan ikan (Kendall dan Kendall, 2006; Jogiyanto, 2005).

Cara manual menimbulkan resiko kesalahan pencatatan data, formulir yang dapat rusak akibat basah atau hilang. Transaksi pengolahan ikan menjadi produk loin beku secara umum terdiri dari proses penerimaan ikan, penimbangan ikan, proses pembersihan dan pemotongan ikan menjadi bentuk loin (proses cutting). Setelah melalui proses penyimpanan dalam ruang pendingin (chillen), dilanjutkan proses retouching/trimming (pembuangan sisa ikan yang tidak berguna).

Jika produk yang dihasilkan sebagai produk beku, maka loin dibekukan disimpan dalam freezer selama semalam. Loin beku dimasukkan ke dalam packing box. Box disimpan sementara sambil menunggu proses stuffing. Beberapa perusahaan pengolahan mencatat secara manual untuk tiap proses tersebut diatas pada formulir manual, selanjutnya setelah pengolahan selesai, staf administrasi melakukan rekapitulasi dalam program excel sehingga membutuhkan tambahan waktu dan tenaga dan hal ini beberapa kali terjadi kesalahan input data terkait dengan human error (Murniyati dan Sunarman, 2000).

\section{BAHAN DAN METODE \\ Waktu dan Tempat Penelitian}

Penelitian ini dilaksanakan pada bulan September 2017 melalui proses analisis alur pengolahan ikan tuna di Bitung, selanjutnya mulai bulan akhir September- Desember dilakukan perancangan sistem, dan 
pengembangan sistem informasi tersebut (Leman, 1997). Selanjutnya dilakukan pengujian sistem dan pada akhir bulan Januari 2018 dilakukan implementasi sistem yang diberi nama sistem TraceTales pada salah satu perusahaan pengolahan ikan tuna di Pelabuhan Perikanan Samudera BitungSulawesi Utara.

\section{Tahapan Perancangan Sistem Informasi}

Tahap perancangan sistem terdiri dari tahapan studi pendahuluan (feasibility study), tahapan analisa proses bisnis, analisis data keluaran dari transaksi yang dicatat. Selanjutnya, dilakukan desain pendefinisian kebutuhan sistem, menggambarkan rancangan antarmuka sistem.

Pada dasarnya terdapat enam tahapan dalam perancangan sistem sebagai berikut :

(1) Survey sistem, melalui identifikasi kondisi kebutuhan pengguna, definisi ruang lingkup sistem dan analisis kelayakan implementasi sistem, bagaimana suatu sistem beroperasi pada lingkungan kerja nantinya, serta dampak dan pemanfaatan sistem nantinya.

(2) Analisa sistem, proses untuk memakai sistem yang ada dengan menganalisa jabatan dan tugas, proses bisnis, ketentuan/aturan yang ada, masalah dan solusinya, dan sumber daya perusahaan.
(3) Desain sistem, merupakan rancang bangun sistem sebagai pedoman bagi programmer dalam mengembangkan aplikasi. Komponen sistem yang didesain meliputi hardware, software, aplikasi dan gambaran/ urutan tugas.

(4) Pembuatan sistem, mencakup data pembuatan database, program aplikasi dan buku petunjuk penggunaan program aplikasi yang telah dibuat.

(5) Implementasi sistem meliputi proses persiapan sistem, sistem pelatihan, pengujian sistem dan pengoperasian sistem .

\section{Analisis Alur Pengolahan Tuna Loin Beku}

Adapun alur pengolahan ikan produk tuna loin beku secara umum terdiri dari tahapan penerimaan ikan dari supplier atau nelayan (proses receiving), penimbangan ikan (berat ikan) dan jenis (dalam bentuk utuh atau bentuk loin). Kemudian dilanjutkan dengan pencucian dan pemotongan ikan dalam bentuk loin, penentuan grade loin (grade ekspor, lokal, atau reject). Penentuan grade dilakukan berdasarkan pengamatan terhadap kondisi ikan yang dipotong, grade ekspor memiliki kualitas loin yang baik. Penentuan kategori grade seperti pada Tabel 1 dibawah ini. 
Tabel 1. Kategori Ikan Tuna Berdasarkan Kondisi

\begin{tabular}{ll}
\hline Kategori & Kondisi \\
\hline Memuaskan & $\begin{array}{l}\text { Daging jernih, berkilau, warna terang, lemak sangat banyak dari luar hingga menembus } \\
\text { kedalam otot daging }\end{array}$ \\
\hline Baik & $\begin{array}{l}\text { Daging agak jernih, agak kurang berkilau, warna kurang terang Lemak sangat banyak dari } \\
\text { luar hingga menembus kedalam otot daging }\end{array}$ \\
\hline Sedang & Daging agak jernih, tidak berkilau, warna agak pucat, ada lemak tetapi hanya diluar \\
\hline Kurang & $\begin{array}{l}\text { Daging hampir pucat, warna kecoklatan, lemak sedikit atau tidak ada, warna daging } \\
\text { seragam. }\end{array}$ \\
\hline
\end{tabular}

Akhir dari proses cutting adalah loin ditimbang dan beratnya dicatat, dikemas dalam plastik, dan disimpan dalam chiller. Setelah penyimpanan selama 2 hari, dilanjutkan dengan proses retouching/trimming (pembuangan sisa loin yang tidak berguna), penentuan grade loin, penimbangan berat, pengemasan dalam plastik vacuum dan pemberian label pada setiap loin, proses vacuum loin, dan pembekuan loin (Murniyati dan Sunarman, 2000). Setelah loin dalam kondisi beku, selanjutnya dilakukan pengemasan/packing loin dalam box karton, box disimpan dalam cold storage. Saat kapasitas terpenuhi, dilakukan proses stuffing atau loading. Pencatatan dilakukan saat box dari cold storage ditempatkan ke dalam truk kontainer. Hasil pencatatan manual selanjutnya direkapitulasi dalam file excel.

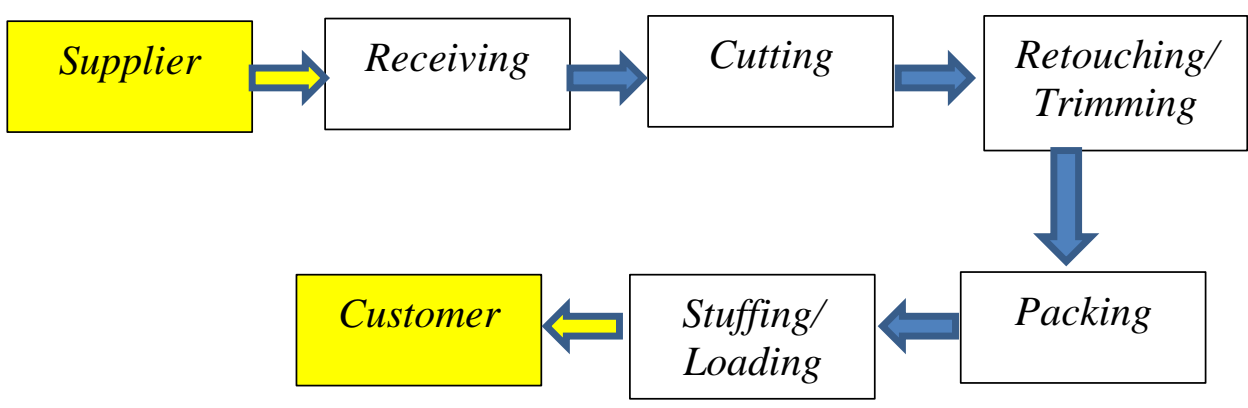

Gambar 1. Alur Pengolahan Ikan Tuna Loin Beku

Berdasarkan data hasil pengolahan ikan tuna pada salah satu perusahaan pengolahan tuna Bitung, selama bulan Februari data pengolahan setiap tahapan, dari jumlah penerimaan ikan dari 15 supplier seperti ditunjukkan pada Gambar 2. 


\section{Total Weight Kg Per Processing}

During 1 Feb - 28 Feb 2018

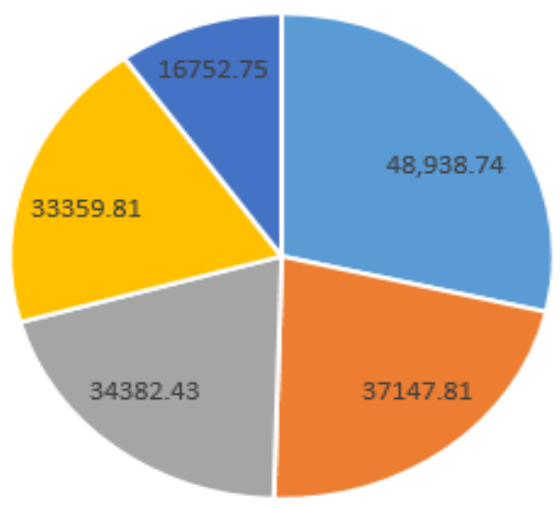

- Receiving | Cutting | Retouching = Packing | Stuffing

Gambar 2. Data Pengolahan Berat Setiap Tahapan Proses

\section{Konfigurasi Perangkat Keras}

Implementasi sistem menggunakan

beberapa perangkat keras dengan konfigurasi tertentu. Data transaksi disimpan secara terpusat pada komputer server dan beberapa tahapan proses menggunakan timbangan digital yang terhubung langsung dengan sistem, printer label dan scanner QR Code untuk memindai data label pada produk. Konfigurasi perangkat keras dapat di lihat pada gambar 3.

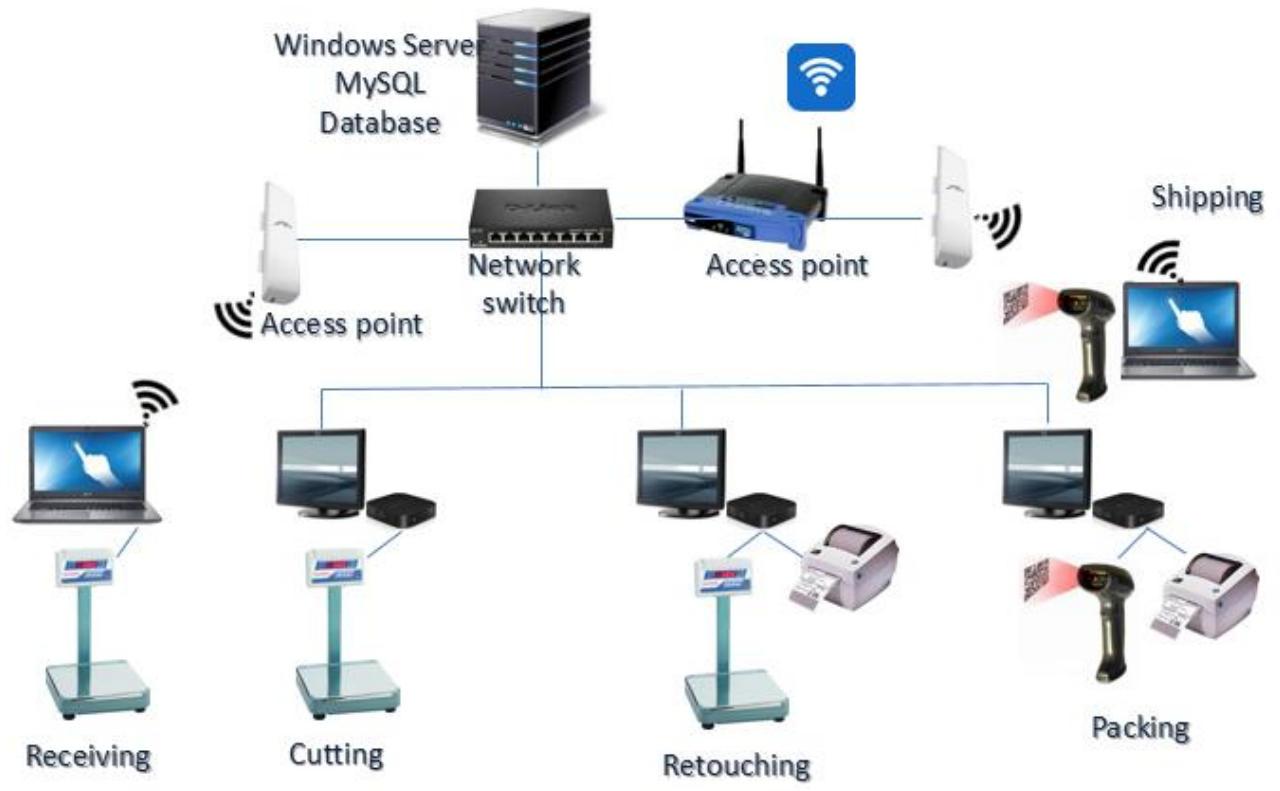

Gambar 3. Konfigurasi Perangkat Keras 


\section{HASIL DAN PEMBAHASAN}

\section{Tampilan Antarmuka Sistem Informasi}

Sistem TraceTales secara umum terbagi menjadi 2 bagian sub menu yaitu sub menu Master Data dan sub menu Transaksi

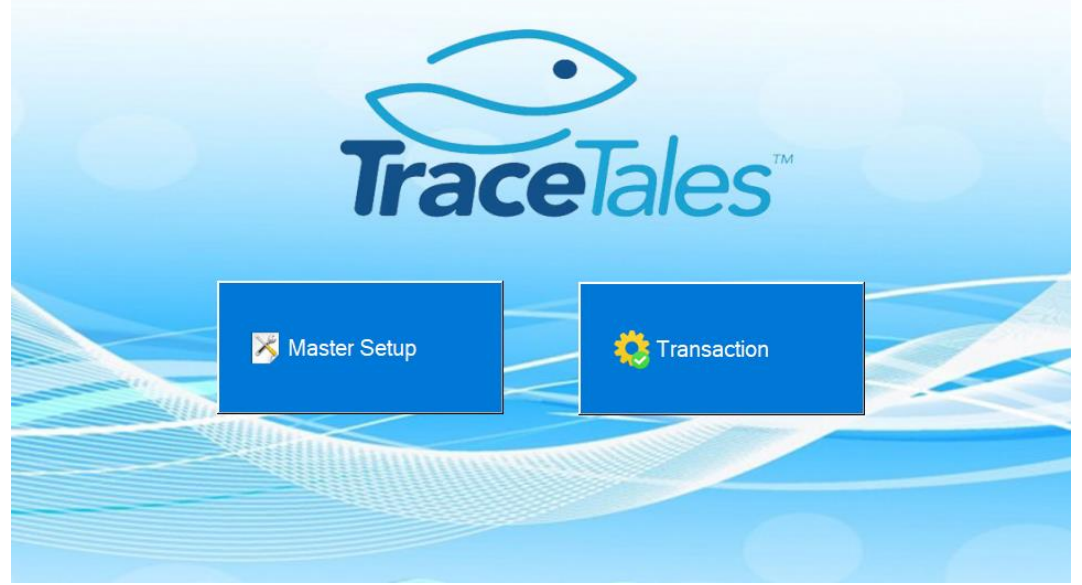

Gambar 4. Tampilan Menu Sistem TraceTales

Sub menu Master Data sebagai tahap inisialisasi data pada sistem untuk menginput data master yang digunakan pada modul transaksi. Master Data terdiri dari data perusahaan pengolahan yang diinput pada modul company profile, data user yang di input pada user setup, data pelanggan yang diinput pada customer setup, data species ikan diinput pada species setup, data grade dan size packing yang di input pada processing categories, data produk akhir diinput pada product setup, dan data supplier disimpan pada supplier setup.

Sub menu transaksi sebagai modul untuk pencatatan transaksi pengolahan ikan terdiri dari modul receiving (penerimaan ikan), modul cutting (proses pemotongan ikan), modul retouching/trimming (pembersihan loin dari sisa produk yang tidak digunakan), modul packing sebagai modul pengemasan produk loin dalam box, dan modul stuffing/loading sebagai modul pengiriman produk ke pelanggan.

Modul Penerimaan (Receiving)

Modul receiving, digunakan untuk mencatat penerimaan ikan berupa jenis ikan utuh dan loin. Sistem membangkitkan kode lot internal (internal lot code) otomatis sebagai kode untuk penelusuran yang terdiri dari 12 karakter, dengan 3 karakter awal menyatakan wilayah tangkapan (area code), 3 karakter berikutnya menyatakan kode supplier, 2 karakter berikutnya menyatakan tahun proses, 3 karakter menyatakan tanggal proses dalam kalender Julian, dan 1 karakter berikutnya menyatakan jenis ikan baik itu ikan utuh 
maupun ikan loin, dan jika terdapat supplier yang menerapkan sertifikasi, maka kode 2 karakter di tulis pada bagian paling belakang, misalnya sertifikasi Fair Trade ditulis FT. Contoh kode lot internal OBC10217109.1.FT.
Pada modul receiving, data yang dicatat adalah jenis ikan, jenis bahan baku, dan berat ikan atau berat loin dalam keranjang.

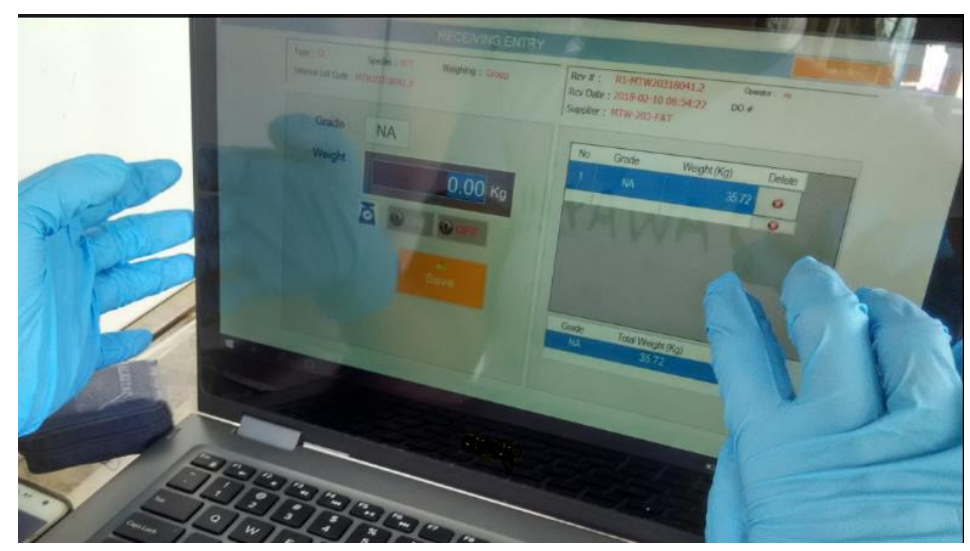

Gambar 5. Proses Entry Data Penerimaan Pada Modul Receiving

\section{Modul Cutting}

Proses cutting sebagai kelanjutan dari proses receiving sebagai proses pemotongan ikan menjadi bentuk loin. Selanjutnya dalam proses cutting dilakukan penentuan grade loin, berupa grade ekspor (kualitas tinggi) atau grade lokal (kualitas sedang) atau grade reject (kualitas rendah). Pada modul ini dilakukan penimbangan setiap loin. Modul cutting terhubung langsung dengan timbangan digital sehingga nilai berat timbangan digital dapat dibaca langsung oleh sistem Cutting. Loin selanjutnya dilakukan proses treatment dan selanjutnya dikemas dalam plastik dan disimpan dalam chiller untuk disimpan sementara.

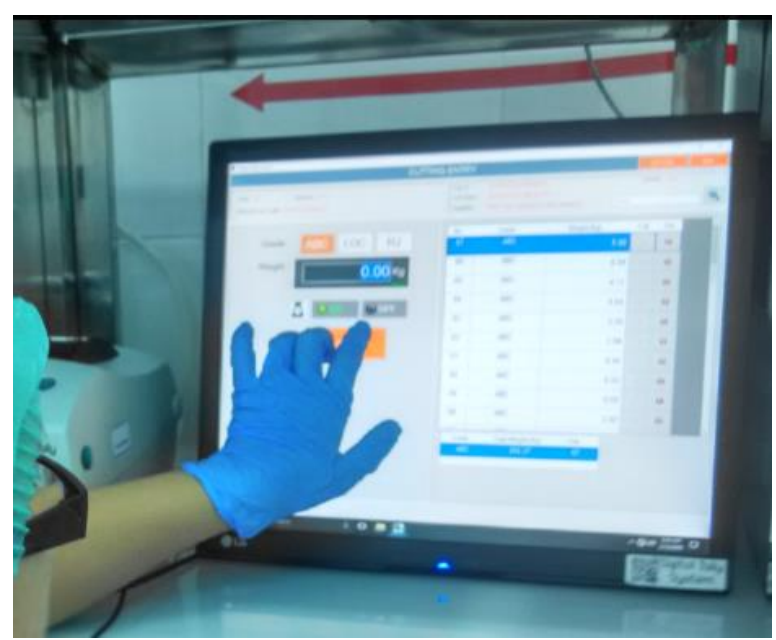

Gambar 6. Proses Entry Data Pada Modul Cutting 


\section{Modul Retouching/Trimming}

Proses retouching/trimming merupakan kelanjutan dari proses cutting, dengan merapikan bentuk potongan loin dan membuang bagian yang tidak berguna. Input data retouching dilakukan dengan memilih internal lot code melanjutkan proses cutting. Selanjutnya ditentukan grade loin dan ditimbang berat dan diberikan keterangan. Saat penyimpanan setiap data loin (pada modul retouching), sistem menghasilkan label
QR Code untuk ditempel pada setiap loin. Informasi label terdiri dari informasi jenis species, grade loin, berat loin, internal lot code, keterangan, asal ikan, lokasi penangkapan (fishing ground), tanggal proses, nama produk. Selanjutnya loin dibekukan dengan disimpan dalam freezer selama 1 malam. Dengan label loin dapat ditelusuri informasi asal supplier, wilayah penangkapan ikan, tanggal penerimaan ikan, negara asal, dan lainnya.

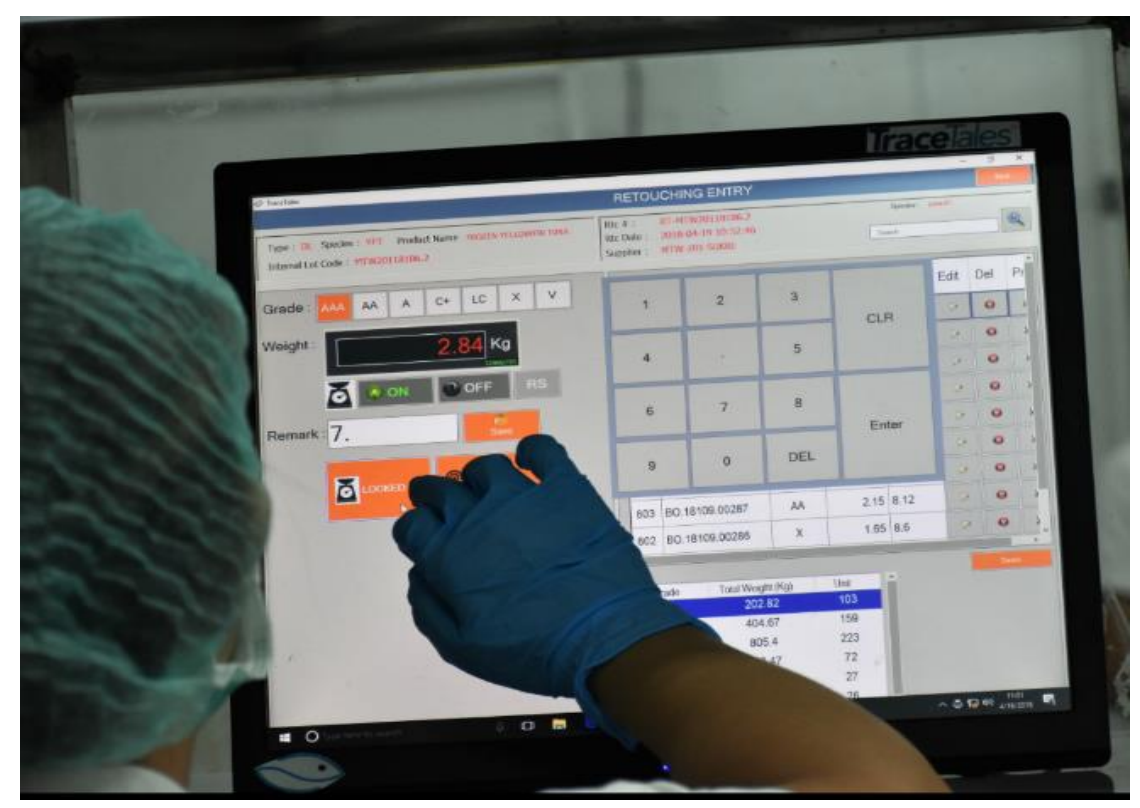

Gambar 7. Proses Entry Data Pada Modul Retouching
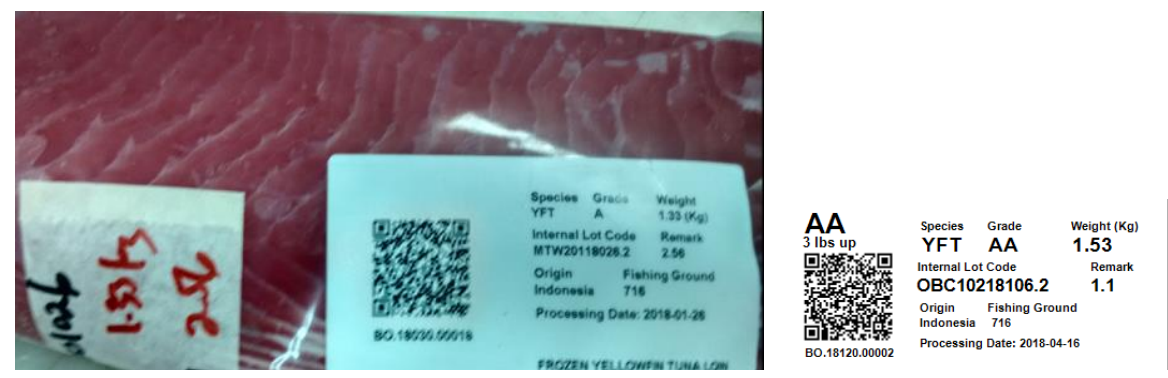

Gambar 8. Labe/Setiap Loin Hasil Proses Retouching 


\section{Modul Packing}

Proses packing merupakan proses pengemasan loin frozen ke dalam box dengan melakukan proses scanning labe/untuk setiap loin yang dimasukkan ke dalam box. Aktifitas input data pada modul packing diawali dengan membuat case number dari modul packing dengan memilih grade dan packing size tertentu. Selanjutnya loin beku yang berisi label di scanning satu per satu agar data loin masuk ke dalam case numbertersebut. Dalam modul packing, terdapat validasi jumlah berat loin maksimum yang diijinkan dalam setiap box, yang terdapat pada print out label packing, jika berat box melebihi berat yang ditentukan maka label packing tidak dapat di print out.

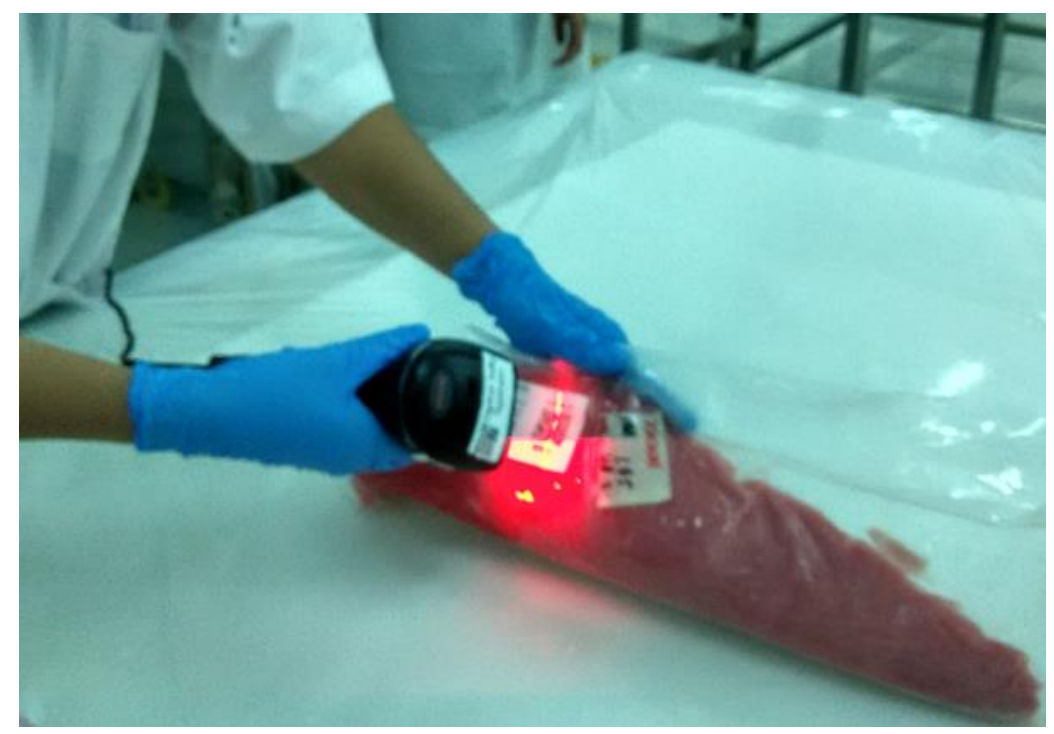

Gambar 9. Proses Packing Dengan Memindai Label Loin Dari hasil entry data loin ke dalam modul packing, selanjutnya sistem dapat master karton.

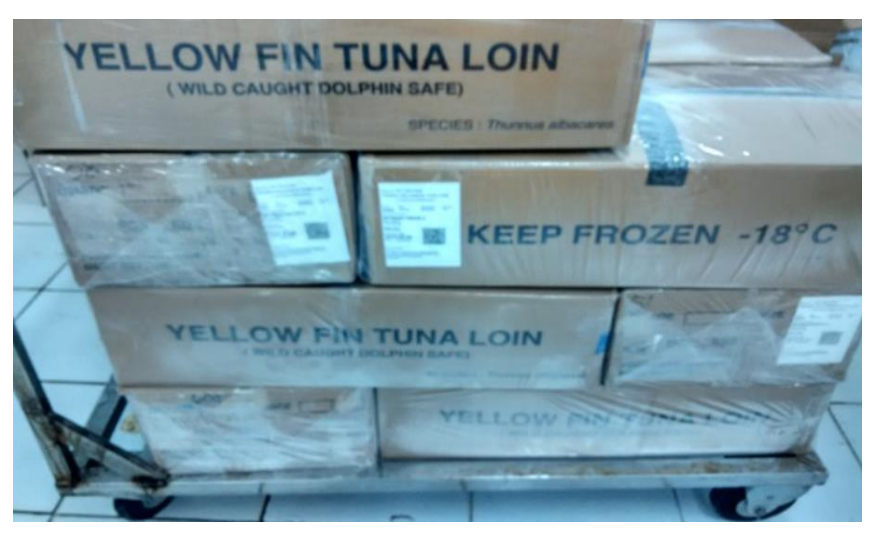

menghasilkan labe/ untuk ditempel pada box

\section{Case №. BO.1804.4461}

FROZEN YELLOWFIN TUNA LOIN ( Thunnus albacares)

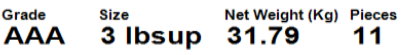

Internal Lot Code

Packing Size
Case $30 \mathrm{Kg}$

Expiry Date

$2018-04-12$
Origin Indonesia

OBC-SUL

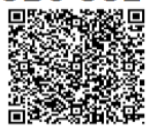

Processed By

PT Perikanan Logistics

Kompleks Pelabuhan Perikanan Samudera,

Aertembaga, North Sulawesi 
Pada label packing terdapat informasi nama produk, grade loin, size loin, berat bersih loin, jumlah loin dalam box, internal lot code (kode internal terbanyak dari loin dalam box), area code wilayah penangkapan ikan, ukuran packing, tanggal produksi, nama perusahaan pengolahan.

\section{Modul Stuffing/Loading}

Proses stuffing/loading merupakan proses untuk menempatkan produk yang dikemas ke dalam box karton ke dalam truk container. Entry data stuffing diawali dengan menginput nomor PO (purchase order), terms pengiriman (shipping terms), tanggal pengiriman, negara asal, informasi kapal seperti nama kapal pengiriman, nomor pengiriman (voyage number), nomor container, nomor seal, nomor bill of ladding, prakiraan waktu keberangkatan (ETD), tujuan pengiriman, dan nama penanggung jawab pengiriman. Nomor packing list dibuat secara automatis oleh sistem. Setiap label box yang dimasukkan ke dalam kontainer, di scanning menggunakan scanner $Q R$ Code, sehingga data box akan terinput ke dalam modul stuffing. Proses ini dilakukan sampai box sudah masuk ke dalam kontainer secara keseluruhan. Setelah proses stuffing/loading selesai selanjutnya pengguna dapat memproses pembuatan Packing List secara otomatis melalui modul stuffing.

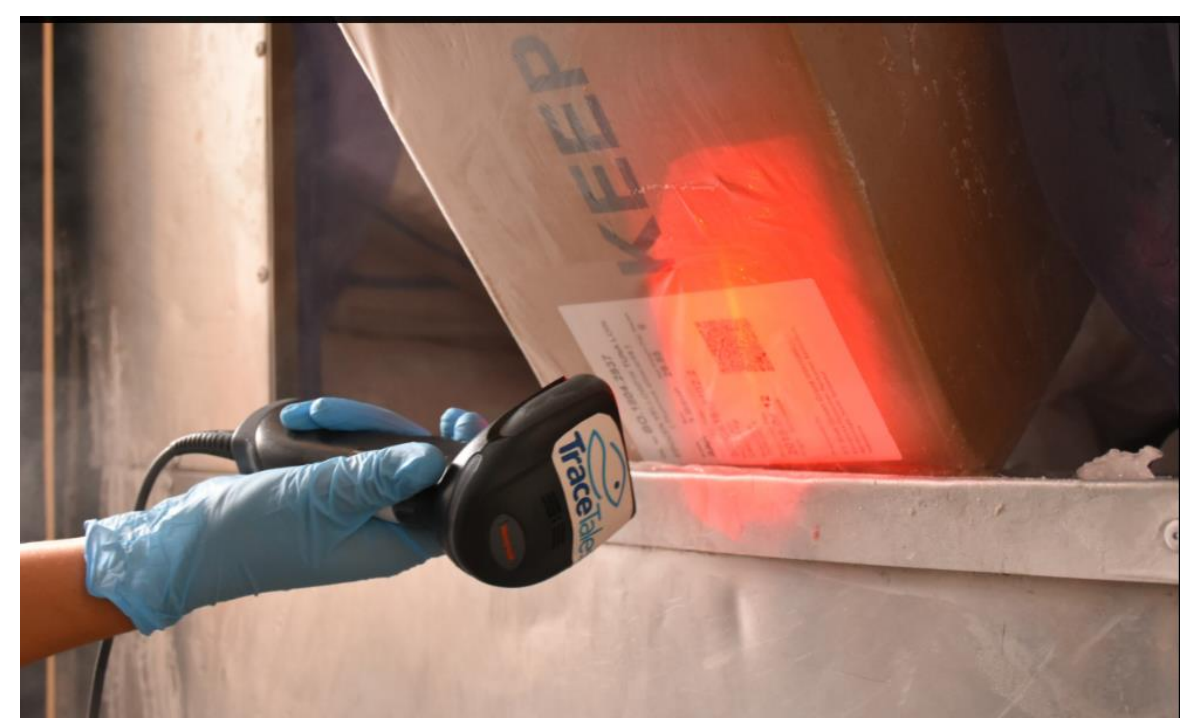

Gambar 11. Proses Stuffing dengan Memindai Label Box

\section{Modul Packing List}

Modul packing list digunakan untuk membuat report Packing List yang dibuat otomatis oleh sistem dan selanjutnya dapat di print out sebagai dokumen pengiriman produk. Modul Packing List menyediakan fitur mengekstrak data ke file excel untuk memperoleh data packing dan data loin yang 


\section{Jurnal IPTEKS PSP. Vol. 6 (11) April 2019:90-101}

ada pada setiap box dari packing list.Selanjutnya melalui modul packing list, Invoice dapat dibuat secara otomatis. Untuk

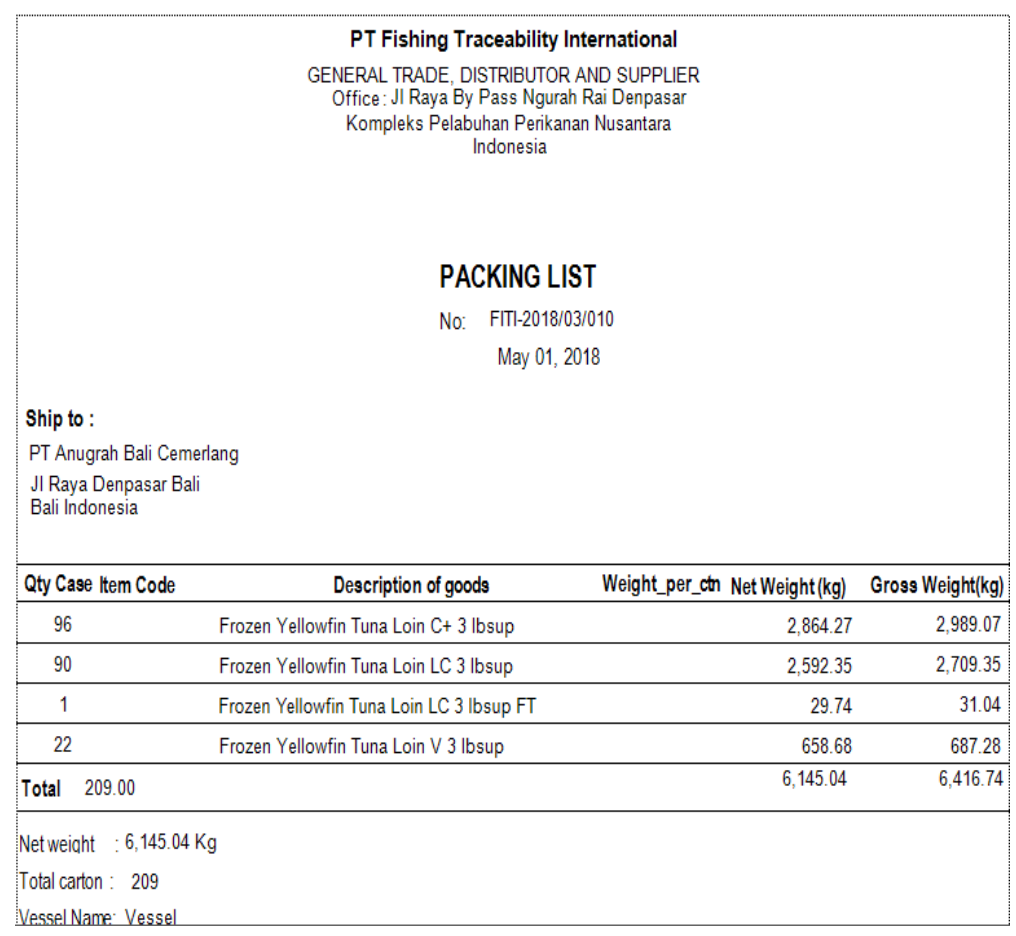

Gambar 12. Tampilan Print Out Packing List

Modul Summary Transaction

Modul ini merupakan modul untuk mengetahui summary dari setiap transaksi berdasarkan kode lot internal. Melalui modul ini dapat di telusuri transaksi penerimaan, transaksi cutting, transaksi retouching/trimming dan transaksi packing berdasarkan kode lot internal masing-masing. Data transaksi secara lengkap dapat di ekstraksi menjadi bentuk file excel untuk keseluruhan tahapan transaksi atau pada setiap tahap transaksi. membuat invoice, setiap produk diisi harga per unit dan selanjutnya Invoice dapat di print. 
1. Implementasi sistem informasi pengolahan ikan tuna memudahkan pengguna dalam mengelola data pengolahan, dan proses pencatatan data lebih cepat karena proses input data dilakukan saat pengolahan berlangsung.

2. Data pengolahan dapat disediakan lebih cepat dan akurat dan penggunaan kode internal lot, memudahkan pengguna dalam melakukan penelusuran asal ikan berdasarkan informasi nama supplier, tanggal penerimaan ikan, lokasi penangkapan ikan (kode batch, dan fishing ground), jumlah dan berat ikan, jenis ikan dan negara asal penangkapan ikan.

\section{UCAPAN TERIMA KASIH}

Terima kasih kepada Yayasan Masyarakat dan Perikanan Indonesia, manajemen perusahaan pengolahan ikan tuna Bitung yang telah banyak membantu dan memberikan dukungan moral dan material sehingga penelitian ini dapat terlaksana dengan baik.

\section{DAFTAR PUSTAKA}

Kendall, K.E. dan Kendall, J.E. 2006. Analisis dan Perancangan Sistem Informasi. Versi Bahasa Indonesia. Edisi Kelima. Jilid I. PT. Indeks Kelompok Gramedia. Jakarta.
Jogiyanto HM. 2005. Analisis Desain Sistem Informasi Pendekatan Terstruktur. Andi Offset. Yogyakarta.

Leman. 1997. Metodologi Pengembangan Sistem Informasi. PT Elex Media Komputindo: Jakarta

Ediyanto. 2017. Manajemen Pengelolaan Sumberdaya Ikan Tuna Indonesia. Proseding Seminar Nasional Inovasi Teknologi - SNITek 2017. Jakarta

Lumingas, L, J, L. B, Wahono. 2010. Studi Aspek Reproduksi Ikan Madidihang (Yellowfin Tuna), Thunnus albacares (Bonnaterre, 1788) Sebagai Dasar Pengelolaan Perikanan Tuna Yang Berkelanjutan. Simposium Pengelolaan Perikanan Tuna Berkelanjutan. Bali.

Rahajeng, M. 2012. Ikan Tuna Indonesia. Kementrian Perdagangan Republik Indonesia. Jakarta.

Murniyati, AS dan Sunarman. 2000. Pendinginan, Pembekuan dan Pengawetan Ikan. Kanisius. Yogyakarta.

Prasetyo, Andhika P. 2010. Perikanan Tuna di Indonesia : Masalah dan Kendala Usaha Perikanan Tuna. Forum Perikanan Indonesia II. Jakarta 19 - 20 November 2010. 